\title{
Book Reviewer Biographies
}

Benjamin Denga is a PhD student in the Adult, Community and Higher Education (ACHE) specialization within the Department of Educational Policy Studies at the University of Alberta. Prior to commencing his doctoral studies, Benjamin worked for many years as an Educator and Program Evaluator within the Training and Quality Assurance Sector of South Africa. Benjamin's research is oriented towards unearthing the incongruity between policy and experience for racialized and marginalized people, and promoting more equitable (and socially just) lived experiences for these groups through informed research/scholarship and advocacy.

Isra Safadi holds a Bachelor of Commerce from the Haskayne School of Business. She has a great passion for making a positive impact on her community through discussion, awareness, and advocacy. She has extensive experience working within the education and health sectors, and is affiliated with international non-profits aimed at equality and integrity. Her business background allows her to have an objective and strategic approach in her explorations.

Rebecca Stares is a second year PhD student with the Faculty of Social Work at the University of Calgary. Rebecca is a Registered Clinical Social Worker in private practice in Calgary and Area. Rebecca focuses on the provision of equine assisted therapy to individuals and families affected by trauma, and other mental health diagnoses. 